Article

\title{
A Comparative Study of Cross-Border and Domestic Acquisition Performances in the South Korean M\&A Market: Testing the Two Competing Theories of Culture
}

\author{
Sung-Jun Lee ${ }^{1}$, Soojin Kim ${ }^{2}$ [D and Joongwha Kim ${ }^{2, *}$ \\ 1 College of International and Area Studies, Hankuk University of Foreign Studies (Global Campus), \\ 81 Oedae-ro, Mohyeon-eup, Cheoin-gu, Yongin-si 17035, Gyeonggi-do, Korea; sungjun_lee@hotmail.com \\ 2 HUFS Business School, Hankuk University of Foreign Studies (Seoul Campus), 107 Imun-ro, \\ Dongdaemun-gu, Seoul 02450, Korea; suekim2009@gmail.com \\ * Correspondence: kim2345678@hanmail.net
}

Received: 13 March 2019; Accepted: 5 April 2019; Published: 17 April 2019

\begin{abstract}
To gain a sustainable competitive advantage through cross-border mergers and acquisitions (M\&As), acquiring firms need to correctly anticipate the consequences of national cultural differences. By comparing the cultural antecedents as well as the performances of domestic M\&As (DMA) and cross-border M\&As (CMA) in the Korean M\&A market from 1999 to 2007, this study aims to gauge whether CMAs can be a viable option for a sustainable growth strategy. This paper tests two conflicting hypotheses $(\mathrm{H})$ regarding the effects of cultural differences. From the perspective of the essentialist ("classic") concept of culture, DMAs will outperform CMAs (H1) because culture clashes may take place less often in DMAs than in CMAs. However, from the perspective of the social constructivist concept of culture, the post-merger performance will be dependent upon the stability and legitimacy of the intergroup status relations between the acquiring and acquired firms regardless of whether it is DMA or CMA (H2). This study also scrutinizes the moderating effects of the level of integration on these two hypothesized relationships ( $\mathrm{H} 3$ and $\mathrm{H} 4$ ). The results of this paper demonstrate that the social constructivist concept of culture overall provides a better theoretical explanation.
\end{abstract}

Keywords: cross-border M\&A; sustainable competitive advantage; post-merger performance; South Korea; the theory of culture; cultural differences; acculturation

\section{Introduction}

The possibility for various synergistic outcomes with acquired firms is one of many incentives that propel firms to engage in mergers and acquisitions (M\&As) as a sustainable growth strategy. However, from the perspective of acquiring firms, approximately 60 to 80 percent of M\&As are either on the verge of recording a loss or a complete failure [1]. Past research has often attempted to explain the high failure rates of M\&As from either a strategic or financial perspective.

However, since the mid-1980s, a growing number of M\&A studies began to look closely into the human side of M\&As, stressing the importance of a post-merger integration which had usually been seen as belonging to the domain of "art" rather than "science". Here, although a wide range of issues were discussed (e.g., speed of integration, employee resistance, autonomy removal and level of integration), cultural differences between the acquiring and acquired firms were (and still are) often seen as one of the most critical determinants that hinder a sustainable M\&A success [2,3].

These studies basically suggested that cultural differences, if significant enough, may cause severe organizational problems and, thus, not only impede the creation of synergistic effects but also have a negative impact on the post-merger performance. In this regard, a good number of prior M\&A studies 
argued that cross-border M\&As (CMAs) with both national and organizational cultural differences were more likely to fail due to poor integration than domestic M\&As (DMAs) with merely organizational cultural differences (double-layered acculturation) [4]. This argument is based on the premise that national cultural differences reflect more fundamental differences in their so-called "core values" than organizational cultural differences [5].

As scholars continue to research the role of cultural differences in M\&As, however, some of them are challenging the prevailing notion in extant literature. For example, several scholars in strategic management suggested that national cultural differences between acquiring and acquired firms may act as a means of accessing and exchanging complementary capabilities that, in turn, may facilitate greater synergies between the acquiring and acquired firms and may positively affect the post-merger performance [6]. In this vein, Morosini and his colleagues discussed in detail the synergistic effects of merging a Swedish firm's team-based and nonhierarchical corporate culture with an Italian firm's culture of creativity and innovativeness [7].

However, empirical research that either examined the correlation between national cultural differences of the acquiring and acquired firms and the results of CMAs or compared the performance of DMAs with CMAs have so far done little to resolve these two conflicting views. For example, while Datta and Puia successfully demonstrated a negative impact of national cultural differences [8], Morosini and his colleagues showed a positive impact [7]. Moreover, Dewenter noted no significant difference between the performance of DMAs and CMAs [9].

Such inconsistent results led us to the following questions: (1) Do CMAs on average lead to less performance than DMAs as laymen often expect; (2) then, under what circumstances and why? To answer the first question, this paper compares the pre- and post-merger performances of 144 DMAs and CMAs that occurred in the Korean M\&A market from 1999 to 2007, the period during which the acquired firms' official financial statements are available. Considering that the majority of acquiring firms do not report the acquired firms' post-merger performance separately, the availability of the acquired firms' financial statements is a unique opportunity to gauge the impact of national cultural differences on M\&A performance in an objective manner.

Also, especially in answering the second question, this paper specifically seeks to test the two different concepts of culture, namely the essentialist and social constructivist concepts of culture in the context of M\&A. Hence, this approach basically presumes that the inconsistent results of the prior studies discussed above in regards to the performance of DMAs and CMAs are based on an inconclusive understanding of culture.

In addition, a number of $M \& A$ studies have successively stressed the importance of the level of integration in generating synergetic effects between the acquiring and acquired firms $[3,10]$. Generally speaking, the high level of integration is seen as a requisite to combining the core capabilities of the acquiring and acquired firms. However, these earlier studies have also observed that the high level of integration is often tied to the level of resistance demonstrated by the acquired employees. In this vein, this paper also intends to examine the moderating effects of the level of integration.

In sum, the main purpose of this study is, thus, (1) to examine empirically whether CMAs perform better or worse than DMAs and, (2) based on the results, to find out exactly under what circumstances national cultural differences in CMAs are likely to be either an opportunity or a threat to a sustainable M\&A success. In addition, previous M\&A studies have often examined the role of national cultural differences simply using the concept of psychic distance or cultural distance. The comparison of CMAs and DMAs in a single country can lead to fruitful—and even robust—results as they are less likely to be "contaminated" by country-specific determinants of CMAs such as macroeconomic and financial markets environments [11]. 


\section{Theoretical Background and Research Hypotheses}

\subsection{The Essentialist Concept of Culture}

The concept of culture that was actively discussed after the 1980s in the field of business studies can be traced back to the essentialist concept of culture discussed primarily in the 1950s to 1960s in the field of cultural anthropology. The essentialist ("classic") concept of culture defines culture as being stable, uniform and composed of basic assumptions that are internally homogeneous but externally exclusionary [12]. The basic assumptions that compose the core of culture are objectively identifiable and can, thus, be observed by conducting surveys, by performing in-depth interviews and through direct observations. The earlier research attempted to understand culture by examining the so-called "cultural dimensions", arguing that the basic assumptions of culture can be identified by looking into how people in different societies respond to various fundamental dilemmas that all societies face without exception, although in different ways.

The basic notion of the essentialist concept of culture is that culture does not change easily-if so, extremely slowly - mainly because it consists of values and norms collectively shared and approved by a group of people as an effective means of solving their problems of external adaptation and internal integration [13]. Over a long period of time, these common values and norms are often readily accepted by group members without question and, thus, implicitly regulate their thoughts and feelings so that they eventually behave more or less in a uniform way. Consequently, not only can culture not be negotiated but also the level of impact that each individual can have on their respective culture is quite limited. In this sense, culture serves as a crucial function in the subsistence of a group. In other words, a group that does not have a common set of values and norms will inevitably be dismantled by severe conflicts amongst group members in the long run. An earlier M\&A research that applied the essentialist view of culture thus argued that culture clashes between the acquiring and acquired firms inevitably resulted in the nondominant acquired firms experiencing a high level of acculturation stress [14].

The essentialist view of culture treats national culture and organizational culture separately. National culture is generally considered as being deeply rooted in basic assumptions that are subconsciously acquired through life-long socialization processes, whereas organizational culture involves specific practices that are consciously acquired in organizations [15]. In this vein, M\&A scholars propose the notion of a "double-layered acculturation", which signifies the difficulties that all acquiring firms in CMA must face as they deal with both a foreign national culture and a new corporate culture.

A number of prior M\&A studies have empirically examined the existence of double-layered acculturations or, in other words, the negative consequences of national cultural differences in the context of CMAs, while the majority of prior studies examined it with samples of CMAs exclusively, considering them as a unique set of empirical phenomena, a handful of prior studies directly compared CMAs with DMAs as well. These studies can arguably be divided into three distinctive groups. The first group of studies looked closely into the impact of national culture on a variety of aspects of a post-merger integration, often stressing the importance of organizational learning and knowledge transfer for creating synergistic gains [16]. The second group of studies examined the relationship between the magnitude of national cultural differences, often as proxied by the cultural distance and post-merger performance [17-19]. The third group of studies, on the other hand, compared the post-merger performance of DMAs and CMAs [20].

Although much has been written, the overall results seem to be somewhat mixed. For example, Ahern and his colleagues, using a sample of 827 CMAs between 1991 and 2008, showed that a greater cultural distance led to lower synergy gains [20]. However, Chakrabarti and his colleagues, using a sample of over 800 CMAs between 1991 and 2004, found that the cultural distance had a positive impact on the post-merger performance, especially in a long-term perspective [21]. Similar results can be found in the other groups of studies as well.

Such a mixed result of prior studies may be, at least in part, the product of methodological differences, especially in regard to the measurement of a post-merger performance. However, one 
can also reasonably argue that the role of national culture in CMAs may be much more complex than usually hypothesized. Here, it is safe to argue that there are at least two working hypotheses that are widely accepted by most M\&A scholars but contradictory from each other. Following the essentialist concept of culture discussed above, the first hypothesis, which we would like to call "culture clash hypothesis", predicts that national cultural differences generally have more "downsides" than "upsides", especially during the early stage of post-merger integration.

On the contrary, the second hypothesis, which we would like to call a "cultural diversity hypothesis", predicts that national cultural differences tend to have more "upsides" than "downsides", mainly because they can be seen as a great opportunity for both the acquiring and acquired firms to prompt interorganizational learning and, thus, to obtain valuable resources and capabilities which they otherwise cannot easily come by in their respective country. For example, from the perspective of the acquired firms in emerging economies, being acquired by firms from Western countries can be seen as a good opportunity to learn more advanced practices in management, which in turn may positively affect the post-merger performance.

Unfortunately, we do not know yet exactly how these two contradictory hypotheses can be effectively reconciled. To tackle the problem, M\&A researchers so far have seemingly taken at least three distinctive yet complementary approaches. Firstly, some of them have deliberately chosen one of the two hypotheses and dismissed the other to clarify their theoretical choices. For example, Huang et al. unmistakably followed the reasoning of the culture clash hypothesis and concluded that, among different cultural values, especially power distance, value differences undermined the long-term post-merger performance [22]. On the other hand, Ahammad et al. clearly adopted the cultural diversity hypothesis and argued that it was not national but organizational cultural differences that had an actual impact on the post-merger performance [16]. Secondly, several researchers argued that national cultural differences had both the impeding and enriching effects simultaneously. For example, Reus and Manont, naming it "the double-edged sword effect," showed that cultural distance was negatively related to post-merger performance through the mediating effects of integration capabilities but also moderated in a positive way through the effect that integration capabilities had on post-merger performance [23]. Thirdly, and lastly, a handful of researchers tried to identify exactly in which circumstances cultural distance is likely to have either a positive or a negative impact on the post-merger performance (e.g., level of integration or prior experience within target countries). For example, Slangen showed that cultural distance had a negative impact at high levels of post-merger integration and a positive impact at low levels, which suggests that a considerable level of autonomy should be given to the acquired firms when cultural distance is relatively large to avoid dysfunctional outcomes during post-merger integration processes [24].

In sum, M\&A researchers seem to have failed to reach a consensus on the effects of national cultural differences on post-merger integration and performance. Nevertheless, one thing is clear: all the prior M\&A studies mentioned above are fundamentally based on the essentialist concept of culture. Hence, one can possibly argue that the main effects of national cultural differences are supposed to be negative, at least in a purely theoretical sense. It does not necessarily mean that we reject the cultural diversity hypothesis. We do believe that, under certain sociocultural circumstances, national cultural differences may beneficially trigger interorganizational knowledge transfer and learning. However, following the logics of the essentialist concept of culture, we also believe it is reasonable to argue that, ceteris paribus, CMAs are likely to experience culture clashes more severely and consequently show less performance than DMAs. Indeed, the destructive aspect of national cultural differences in CMAs have been widely acknowledged and well-documented, e.g., the Daimler-Chrysler merger. Based on the discussion so far, this study thus preliminarily hypothesizes as follows:

Hypothesis 1. CMAs with both national and organizational cultural differences show, on average, a lower rate of post-merger performance than DMAs with only organizational cultural differences. 


\subsection{The Social Constructivist Concept of Culture}

Aside from the three approaches discussed above, several M\&A researchers looked for an alternative way to solve the contradiction between the two hypotheses by putting distance from the essentialist concept of culture and looking at culture from a different theoretical and ontological angle. From the essentialist concept of culture, it is possible to predict whether culture clash may occur or not-and to some extent the characteristics of them-before M\&As actually take place by quantifying and classifying cultural orientations of the acquiring and acquired firms. However, a relatively small number of research papers argued that the essentialist concept of culture is too deterministic and, therefore, inappropriate in offering a comprehensive explanation regarding the complicated cultural phenomena occurring in the context of M\&As. As an alternative view, the social constructivist concept of culture was offered where culture was seen not just as content but as a process. Here, culture is defined as (1) "a constantly ongoing attempt of the collective to define itself and its situation" [25] (p. 23), (2) a "communication apparatus" [26] or (3) the "cultural community of common meaning" [27].

The social constructivist concept of culture assumes that culture is a social construction emerging through the relationships and interactions of group members. Consequently, depending on the consensus of group members, the constructs of culture can be constantly formed, sustained, changed or destroyed. Culture is an ever-changing theory or idea that may be commonly held by a group or not. In this sense, culture is not determined by an immutable law and, thus, cannot be defined by references such as countries, corporations, organizations or religions. Instead, cultural boundaries are always in a state of flux without any clear boundaries.

Culture is not about imposing a specific set of values and norms as to what is acceptable but is consciously created by the different thoughts and feelings that each group member has in their own positions [28]. By being consciously created, culture is, therefore, used as a means by group members to accomplish a specific purpose. It is through culture that group members validate the existence of their group by subjectively interpreting the situations currently faced. As a result, culture is constantly being newly formed and changed. In this sense, culture cannot be seen as a way to control a group as one but, rather, is a pragmatic tool that is defined not by its properties but by its use. Hence, any culture requires a subjective interpretation of how "insiders" actually think and feel, if it is to be "truly" understood and, thus, inevitably ambiguous $[29,30]$. Culture is not simply given but is to be constantly negotiated and, therefore, cannot exist separately from the subjective consciousness of the group members.

From this perspective, the concepts of communication, identity or self-image inevitably bear a considerable weight. First, given that the social construction of culture occurs through conversations, written correspondence and other various forms of communication, one could view culture as a communication apparatus [26]. In other words, in today's modern world that is becoming ever more complicated, it is culture as a communication means that integrates and binds a group together. Second, people are able to enhance their social identity by attaching a "special" meaning to what seems plausible as a common goal for the group that they belong to. In this context, culture is a means of forming a common identity as a group [25]. From the perspective of organizational change, identity can, therefore, be a powerful theoretical tool to use to explain various cultural phenomena, e.g., cultural transformation or culture clash.

Prior M\&A studies that looked into the cultural aspects of M\&As from the social constructivist perspective viewed a culture clash as stemming from identity conflicts rather than objective differences in value orientations [25,31-33]. In other words, culture clashes do not stem from differences in values and norms between the acquiring and acquired firms. Instead, there are most likely various situational reasons as to why acquired employees have an "us" versus "them" mentality in refusing to identify themselves with the members of the acquiring firms.

Of course, when cultural conflicts between the acquiring and acquired firms are severe enough, such "objective" differences in value systems may be perceived as the source for the culture clash. However, a handful of prior studies refuted this position by pointing out that the real underlying cause is rather related to identity issues. For example, Kleppestø observed this by utilizing the ethnographic 
research method in examining the merger between AB Bofors and FFV Ordnance in Sweden [25]. He spent circa six months at the merged firm, namely Swedish Ordnance, tracking communication processes and changes in social relationships after the merger. Surprisingly, the results showed that the initial cultural similarities or differences between the premerger organizations had no significant impact on the integration outcomes. Moreover, any attempts to deliberately eliminate premerger identities, in fact, made it harder for employees to interact with one another, which ultimately led to deeper interorganizational conflicts [34-37].

To summarize, cultural differences between the acquiring and acquired firms cannot possibly be attributed to conflicting objective value systems as claimed by the essentialist concept of culture. Therefore, the argument that CMAs are likely to face greater difficulties than DMAs as a result of cultural differences no longer seems to have relevance. Rather, such conflicts may arise when acquired employees fail to identify themselves as members of a new group because they subjectively perceive their new group identity as being less attractive than their old group identity. It provides an alternative explanation as to why prior M\&A studies failed to identify the main effects of national cultural differences defined in terms of the essentialist concept of culture.

In real life, acquired employees may be willing to keep their old identity for a variety of reasons. However, it would be safe to assume that acquired employees are highly unwilling to discard their old group identity, especially when they perceive that either (1) their firms are still doing well and, thus, do not deserve to be acquired or (2) the acquiring firms are not good enough to acquire their firms (although M\&As are seen as being one of the feasible options). In other words, when the stability and legitimacy of intergroup status relations between the acquiring and acquired firms are low, the acquired employees are likely to see their post-merger status as being unjustifiable and, thus, would rather try to stick to their old group identity, which in turn may trigger a variety of interorganizational conflicts during the post-merger integration processes. Based on the discussion so far, the following hypothesis is proposed:

Hypothesis 2. The stability and legitimacy of intergroup status relations between the acquiring and acquired firms have a positive impact on the post-merger performance in both DMAs and CMAs.

\subsection{The Moderating Effect of the Level of Integration: The Essentialist Concept of Culture}

A vast number of prior M\&A studies put great emphasis on the importance of post-merger integration processes for M\&As to be successful. Many of these studies have paid particular attention to, among others, the effects of the level of integration [38]. From a cultural perspective, it implicitly suggests that it is possible to avoid the negative effects associated with cultural differences if the "right" level of integration is pursued.

In general, a high level of integration is required to obtain the synergy effects from related or horizontal M\&As. Such an integration makes it possible to integrate functional activities that are unnecessarily duplicated and to use valuable resources efficiently. However, achieving such high levels of integration requires a reshuffling of the management structure of the acquired firm which could subsequently lead to the acquired employees feeling demoralized or worse and lead to an employee strike. By contrast, pursuing a low level of integration would lead to a relatively low level of resistance by the acquired employees at the cost of having a negative impact on the synergistic effects of the merger. The positive as well as negative impacts that the level of integration can have on the post-merger performance have been validated through numerous studies. For example, Datta and Grant showed that, while a high level of integration had a negative impact on the post-merger performance in unrelated M\&As, it had no distinct impact in related M\&As where the latent synergy effects were expected to be relatively larger, which in turn suggests that the positive and negative effects of the post-merger integration nullified each other [39].

In the similar vein, prior M\&A studies that utilized the essentialist concept of culture often stressed the importance of the mutually dependent relationship between cultural differences and the level of integration [40]. Put another way, when cultural differences are clear as in the case of CMAs, 
a high degree of integration will significantly increase the resistance level of the acquired employees. Such cultural incompatibilities are not a matter for negotiation, and therefore, the essentialist concept of culture would suggest a low level of integration, which is limited and gradual in an effort to avoid employee resistance while also creating an atmosphere conducive to producing synergy. On the other hand, if cultural differences are relatively insignificant, the negative impact that cultural incompatibilities have on synergy is likely to be negligible. By quickly seeking a high level of integration, acquiring firms can expedite the learning process across organizations, generate synergies and improve the post-merger performance. Presuming that cultural differences between the acquiring and acquired firms are likely to be more prominent in CMAs than in DMAs, the following hypothesis is proposed:

Hypothesis 3. The level of integration has a moderating effect on the relationship between cultural difference and post-merger performance. Specifically, a high level of integration has a positive impact on post-merger performance in DMAs but a negative impact in CMAs. On the other hand, a low level of integration has a positive impact in $C M A$ s but a negative impact in DMAs.

\subsection{The Moderating Effect of The Level of Integration: The Social Constructivist Concept of Culture}

As already discussed elsewhere, if the stability and legitimacy of intergroup status relations between the acquiring and acquired firms could be more accurate than "objective" cultural differences in predicting the occurrence of interorganizational conflicts and, thereby, post-merger performance, the level of integration could arguably have a moderating effect on the relationship between them as well.

From the perspective of the social identity theory, Rousseau argued that the success and failure of a post-merger integration was more dependent on the social context surrounding the acquisition (e.g., whether the acquisition was the one and only option for survival of acquired firms) rather than the details of the post-merger integration (e.g., the method, level, scope or speed of integration) [41]. In fact, if the acquired employees subjectively perceive that the high level of integration is an organizational objective or a matter that will help the organization survive, then they are likely to welcome such a level of integration [42,43]. In other words, when the stability and legitimacy of intergroup status relations are perceived to be high, there is a high probability that the acquired employees will regard an organizational integration that is solely initiated by the acquiring firms as being necessary or, at the very least, unavoidable. Within this social context, it becomes possible for the acquiring firms to implement various organizational changes with very little resistance, which will, in turn, have a positive impact on the post-merger performance. However, when the stability and legitimacy of intergroup status relations are low, there is a high probability that the acquired employees will consider an organizational integration as being irrational and even excessive interference. This will eventually lead to complicated social cultural problems such as culture clashes and interorganizational conflicts [36]. In such cases, the acquiring firms should seek to implement a low-level or gradual organizational integration in order to minimize the negative effects of such problems on the post-merger performance. Hence, the following hypothesis is proposed:

Hypothesis 4. The level of integration has a moderating effect on the relationship between the stability and legitimacy of intergroup status relations and post-merger performance. Specifically, a high level of integration has a positive impact on the post-merger performance when stability and legitimacy is high but a negative impact when low. On the other hand, a low level of integration has a positive impact when stability and legitimacy is low but a negative impact when high.

\section{Method}

\subsection{Data Collection and Sampling}

The initial sample size was extracted from Thomson Financial SDC Platinum database. By searching through all DMAs and CMAs targeting Korean firms from the period of 1999 to 2007, a total of 3817 cases were identified. 
For purposes of this empirical study, working under the presumption that M\&As were quantitatively and qualitatively vastly different before and after the 1997 Asian financial crisis, all M\&As occurring before 1999 were excluded from the sample pool. Also, since the introduction of the Korean International Financial Reporting Standards (K-IFRS) in South Korea in 2007, many of the acquiring firms in the sample have discontinued offering separate financial statements of the acquired firms. Therefore, all M\&As that took place after year 2007 were excluded as well. The results indicated that there were 840 cases of CMAs, 2682 cases of DMAs and 295 cases where the acquiring firm's nationality was unknown.

In order to find the appropriate sample, we removed the following cases from our sample pool: 80 cases labeled as "rumor" or "discontinued"; 317 cases labeled as "intended", "seek buyer", "seek buyer withdrawn" and "withdrawn"; and 12 cases labeled as "unknown". Any M\&As where the acquisition amount was less than 10 million dollars were removed, resulting in 623 cases being removed from the sample. Additionally, the acquired firms with the SIC industry classification codes where the first number was 1, 6 or 9 were also eliminated. Specifically, 101 cases involving oil and mineral businesses with codes $1 x x x ; 486$ cases involving finance and insurance with codes 6xxx; and 20 cases involving social-based facilities such as wastewater treatment facilities, refuse incineration plants and power plants with codes 9xxx were all excluded. Likewise, acquired firms with the SIC code starting in 7 except 73xx (business services) were also excluded from the sample pool. This code includes, for example, hotels and golf courses, equaling 47 cases. Additionally, acquisitions undertaken by acquiring firms with the SIC code starting in 6, which totaled 606 cases, were excluded as the majority of them seemed to be financial investments without seeking synergetic effects. Through this process of elimination, 2292 cases were removed from the sample, leaving behind 1525 cases, of which 426 were CMAs and 1099 were DMAs.

Each of the 1525 cases were individually reviewed using various sources such as the Financial Supervisory Services' DART system, the Korea Exchange's listing system (KIND), Korea's NICE Information Services (KISVALUE), Standard \& Poor's Compustat, press releases and the websites for the acquiring and acquired firms. Any case that was unable to meet the following standards was excluded from the sample pool.

(1) The acquiring firm had more than a 50\% acquisition in the acquired firm (112 CMAs and 424 DMAs excluded)

(2) The financial statements for the acquired firm are available (57 CMAs and 296 DMAs excluded)

(3) The M\&As have the goal of generating synergy and not financial "money game" (25 CMAs and 44 DMAs excluded)

(4) Additionally, M\&As involving affiliates within the same company, franchises and subsidiaries of MNCs were also excluded (165 CMAs and 258 DMAs excluded)

Through this process described above, 67 CMAs and 77 DMAs were finally selected. Each of the acquired firms in these samples had publicly announced financial statements, which helped to ensure a high degree of accuracy in measuring the M\&A performance.

\subsection{Measures}

Secondary data to measure the variables was obtained from various domestic and international databases. Specifically, information on Korean firms was obtained from KISVALUE and DART. On the other hand, information on non-Korean firms was obtained from the Compustat or US Securities and Exchange Commission's EDGAR system. Specifically, the variables in this study were measured as follows:

\subsubsection{Independent Variable: Cultural Difference}

Any M\&A case in the sample with non-Korean acquiring firms are coded as 1 (CMA), while Korean acquiring firms are coded as 0 (DMA). 


\subsubsection{Independent Variable: The Stability and Legitimacy of Intergroup Status Relations}

This paper measures the stability and legitimacy of intergroup status relations in two different ways.

(1) The acquired firm's industry-adjusted debt-assets ratio = the acquired firm's debt-assets ratio premerger/industry average debt-assets ratio premerger

(2) The relative size of the acquiring and acquired firms $=$ the acquired firm's sales premerger/acquiring firm's sales premerger

Although one can argue that stability and legitimacy are two separate entities, they can also be seen as being closely related to each other in a sense that the high level of legitimacy is an essential prerequisite for the high level of stability. In addition, intergroup status relations, here, signify the belief about the nature of relations between ingroup (e.g., acquired employees) and relevant outgroups (e.g., acquiring employees) [44].

For the stability and legitimacy of intergroup status relations between the acquiring and acquired firms to be high, it is crucial that the acquired employees regard the acquisition as desirable or, at least, inevitable. This paper presumes that they may do so under the following two conditions: (1) the acquired firm has been performing extremely poorly, and thus, its employees regard the acquisition as inevitable, or (2) the acquiring firm is generally regarded as being far "superior" to the acquired firms, and thus, the acquired employees see the acquisition as a great chance to expand their business.

For the first condition, this paper measured the acquired firm's debt-assets ratio prior to acquisition. In other words, if the acquired firms were heavily indebted and thus bankruptcy seemed to be unavoidable prior to acquisition (a high debt-assets ratio), the acquired employees could perceive their "inferior" status as given without severe resistance. Since the debt-assets ratio might vary significantly depending on the industry, this paper calculated the ratio of the acquired firm's debt-assets ratio to the average industry debt-assets ratio. The latter was extracted from KISVALUE using the fourth digit of the KSIC code. When a measurement exceeded 1, this meant that the acquired firm's debt-assets ratio prior to acquisition was relatively higher than the average debt-assets ratio of the relevant industry. If the financial statements for the two years prior to acquisition were available, then the average of the two was used. If such financial statements were unavailable, then data from only one year was used.

For the second condition, the paper measured the relative size of the acquiring and acquired firms in terms of sales. If the acquiring firms were far bigger than the acquired firms (e.g., Google acquired an unknown business venture), the latter could accept the relatively "superior" status of the former and, thus, perceive M\&As as more stable and legitimate. For measurement, sales figures of the two years prior to acquisition were averaged. If the value exceeded 1, it meant that the acquired firm's sales figures exceeded those of the acquiring firm.

\subsubsection{Moderator Variable: The Level of Integration}

Prior studies that empirically examined the level of integration between the acquiring and acquired firms exclusively measured it using the survey method $[45,46]$. However, this paper rather seeks to measure it in an objective manner using the following variables: (1) CEO turnover and (2) downsizing. These measurements are based on the presumptions that the level of integration is high when acquiring firms try (1) to forcefully implement their own routine and repertoires in the acquired firms and/or (2) to aggressively seek to achieve economies of scope. While the first alternative often requires a CEO replacement who is knowledgeable of the business in the acquiring firms, the second alternative requires the elimination of duplicate facilities and departments.

Concerning CEO turnover, acquired firms that replaced the CEO within two years post-merger were coded a 1 while others were a 0 . When a joint management continued for a minimum of two years, such firms were coded a 0 . Concerning downsizing, the ratio of the number of acquired employees two years before the merger to the number of acquired employees two years after the merger was 
calculated. Therefore, when the relevant ratio was smaller than 1 , this meant that any reorganizing or restructuring done after a merger led to a reduction in the number of employees at the acquired firm. Of course, when the ratio was greater than 1 , it meant that there was a high probability that the level of integration was high. However, job insecurity stemming from the merger would most likely lead to an intense resistance by the acquired employees more than any other change.

\subsubsection{Dependent Variable: Post-Merger Performance}

The absolute majority of prior M\&A studies have measured the post-merger performance either by surveying CEOs or high-level managers [47] or by using stock market-based performances [21] of the acquiring firms, presumably because most of acquiring firms do not make public the acquired firms' performance separately. Therefore, the "correct" measurement of an M\&A performance can be tricky as there are many different alternative measures with different pros and cons [48].

However, in South Korea, it is possible to obtain separate financial statements of the acquired firms up until 2007, before K-IFRS required all eligible firms to report consolidated-instead of separate-financial statements. Also, considering that this study basically looks at M\&As from the angle of acquired firms, it is of a great importance to correctly gauge the acquired-not the acquiring-firms' performance, if possible. Therefore, this study measures the acquired firms' preand post-merger performances using their official financial statements. Specifically, we calculated the acquired firm's return on assets (ROA) five years before and after the acquisition as described below. The period of five years after the acquisitions was expected to be long enough to cover the whole post-merger integration processes.

(1) The acquired firm's ROA = the acquired firm's net income/acquired firm's total assets

(2) The acquired firm's industry-adjusted ROA = the acquired firm's return on assets-the industry's return on assets based on

Besides ROA, the post-merger performance can also be measured in a number of other ways. However, this paper uses ROA because ROA along with the return on equity (ROE) are the two most commonly used measurements by earlier studies researching post-merger performance. Given that acquired firms that experienced a capital erosion prior to acquisition were already included in the sample pool, the ROE could not be used. The ROA of the starting year of acquisition, year 0, was excluded. Moreover, for M\&As that occurred in 2006 and 2007, only the performance results for a maximum of four years and three years, respectively, were included. The industry average ROA was extracted based on the fourth digit of the acquired firm's KSIC code from KISVALUE.

\subsubsection{Control Variables}

The following two control variables were used in this study. First, the relatedness of the acquiring and acquired firms was measured by matching the third digit of the SIC codes (extracted from Thomson Financial SDC Platinum database) for each of the acquiring and acquired firms. The related M\&As were coded with 0 , while the unrelated M\&As were coded with 1 . Second, the Thompson Financial SDC Platinum database categorizes whether the acquiring and acquired firms are in technology-intensive industries. Using this information, the variable "high technology" was coded with 1 if the acquired firm was in a technology-intensive industry, otherwise it was coded with 0 . Given that technology-intensive industries focus more on labor, to a greater extent than capital-intensive industries, the degree to which a culture clash could affect the synergy and post-merger performance is relatively larger than in any other industry.

\section{Results}

\subsection{Comparison of Post-Merger Performance of DMAs and CMAs}

In order to compare the differences in the post-merger performance of DMAs and CMAs, we 
conducted the independent sample $t$-test using the acquired firms' ROA and industry-adjusted ROA respectively. The results of the test are discussed below.

First, the acquired firms' premerger ROA was found to be significantly higher in CMAs than in DMAs. Similar results were also found in the case of an industry-adjusted ROA. This difference was especially prominent in ROA $t-4(\mathrm{M}=-0.0999$ for DMA and 0.0110 for CMA $)$ and ROA $t-2$ $(\mathrm{M}=-0.1587$ for DMA and 0.0090 for CMA). Of course, there are many ways to interpret the results. For example, foreign (non-Korean) firms might be more cautious than domestic (Korean) firms when acquiring a domestic firm since the former has comparatively less information than the latter on the domestic M\&A market as well as the targeted firm itself. Given this context, we can implicitly understand that, regardless of whether it is before or after acquisition, the standard deviation value is significantly higher for DMAs than CMAs because domestic firms are more likely than foreign firms to accept the risks associated with M\&As.

Second, when comparing the acquired firms' post-merger ROA by year, there was statistically no significant difference between DMAs and CMAs. An industry-adjusted ROA showed similar results. To see if there were any changing trends in the acquired firms' ROA for both DMAs and CMAs, we conducted the paired sample $t$-test to compare the acquired firms' ROA with the industry-adjusted ROA. The results of the test indicated that regardless of whether it was a CMA or DMA, the acquired firm post-merger ROA was less than the industry-adjusted ROA. In the case of CMAs, ROA $t+1$ $(\mathrm{t}=-1810, p<0.1)$, ROA $\mathrm{t}+2(\mathrm{t}=-1.861, p<0.1)$, ROA $\mathrm{t}+3(\mathrm{t}=-2175, p<0.05)$ and ROA $\mathrm{t}+5$ $(\mathrm{t}=-1941, p<0.1)$ were shown to be statistically significant. For DMAs, ROA $\mathrm{t}-4(\mathrm{t}=-2477, p<0.05)$, ROA $\mathrm{t}-3(\mathrm{t}=-1.687, p<0.1)$, ROA $\mathrm{t}-2(\mathrm{t}=-3.035, p<0.01)$, ROA $\mathrm{t}-1(\mathrm{t}=-1.804, p<0.1)$, ROA $\mathrm{t}+2(\mathrm{t}=-1.870, p<0.1)$ and ROA $\mathrm{t}+3(\mathrm{t}=-2.853, p<0.01)$ were shown to be statistically significant. The acquired firms' ROA was always lower than the average of the industry-adjusted ROA. These results strongly support the findings of prior M\&A studies that the failure rate of M\&As is $60-80 \%$. Another interesting finding is that, while the acquired firms' mean value in DMAs progressively increased, for CMAs, such values would repeatedly fluctuate between rising and falling. It would be worth conducting a larger study in the future to closely examine these changes.

\subsection{Analysis of the Moderating Effect of the Level of Integration}

The moderating effect of the level of integration was tested using a moderated multiple regression analysis. We used a total of four dependent variables in the regression analysis. (1) The acquired firms' short-term ROA was calculated as the mean value ROA for 1-2 post-merger years minus the mean value ROA for 1-2 premerger years, and (2) the acquired firms' long-term ROA was calculated as the mean value ROA for 4-5 post-merger years minus the mean value ROA for 1-2 premerger years. Thereafter, two additional dependent variables were added: (3) The acquired firms' short-term industry-adjusted ROA was calculated by subtracting the industry-adjusted mean ROA for the 1-2 premerger years from the acquired firms' industry-adjusted mean ROA for the 1-2 post-merger years, and (4) lastly, the acquired firms' long-term industry-adjusted ROA was calculated by subtracting the industry-adjusted mean ROA for 1-2 premerger years from the acquired firms' industry adjusted mean ROA for $4-5$ post-merger years.

Descriptive statistics along with the $t$ - and z-tests for the mean and proportional comparison of two independent samples (DMA and CMA) is presented in Table 1. The table shows that there are significant mean differences in the acquired firms' long-term ROA and long-term industry-adjusted ROA between DMAs and CMAs. Moreover, there were statistically significant differences between DMAs and CMAs regarding the premerger social situations surrounding the acquiring and acquired firms, such as the debt-assets ratio and relative size. More often than not, in the case of DMAs, the acquired firms faced a replacement of their CEOs. A plausible explanation for this is that the acquiring firms in a CMA generally perceive cultural differences as a serious threat to M\&A success and, thus, are more reluctant to replace CEOs (seeking a low-level integration) than the acquiring firms in a DMA. 
Table 1. Descriptive statistics of DMAs and CMAs.

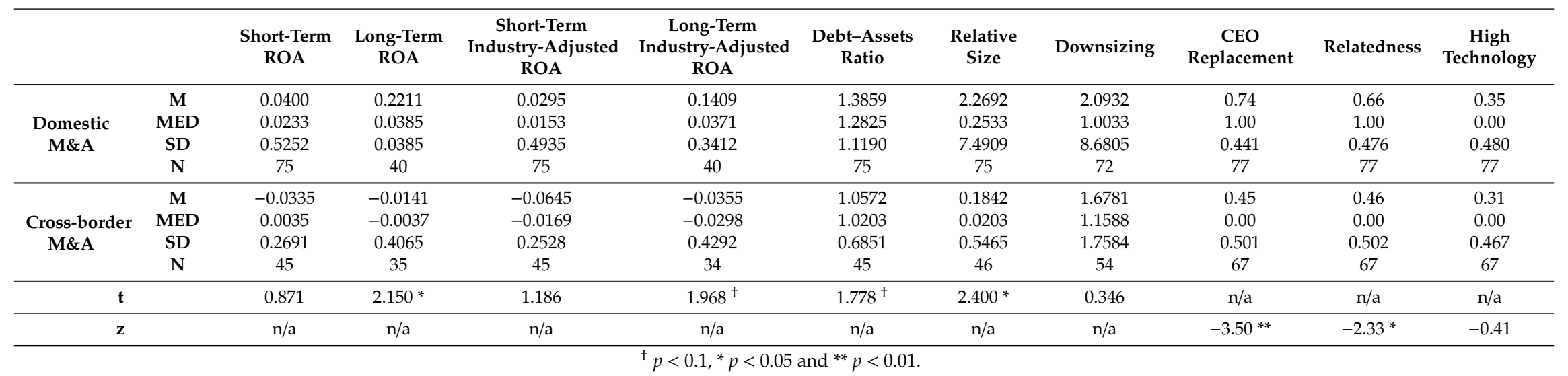


The correlation matrix of all the variables is presented in Table 2. A cultural difference was found to have a statistically significant negative correlation with the acquired firms' long-term ROA $(\mathrm{r}=-0.244, p<0.05)$, CEO replacement $(\mathrm{r}=-0.298, p<0.01)$ and relatedness $(\mathrm{r}=-0.201, p<0.05)$. On the other hand, the debt-assets ratio had a statistically significant positive correlation with the acquired firms' short-term ROA $(r=0.243, p<0.01)$ and short-term industry-adjusted ROA $(r=0.246$, $p<0.01$ ). A CEO replacement was found to have a significantly positive correlation with almost all the other dependent variables. Moreover, there were no significant correlations among the independent variables, meaning that multicollinearity should not be an issue here.

The results of a moderated multiple regression analysis are shown in Tables 3 and 4 . If we take the results of the entire analysis and highlight the key observations, they would be as follows: First, in distinguishing between DMAs and CMAs, when using the acquired firms' long-term industry adjusted ROA as a dependent variable, the result was a negative value $(p<0.1)$. This result supports hypothesis 1 in that DMAs have more potential for excess profit than CMAs from a long-term perspective.

Second, regardless of the industry adjustment on the post-merger performance, the results of the analysis show that the debt-assets ratio has a positive correlation with the short-term post-merger performance. Regardless of whether it is a CMA or DMA, acquired firms with high premerger debt-assets ratios enjoyed a relatively higher degree of performance in the early stages of post-merger compared to those acquired firms that had lower premerger debt-assets ratios. Such results support hypothesis 2. On the other hand, the relative size did not have any significant impact on the post-merger performance. Relative size in terms of sales figures extracted from consolidated or combined financial statements were found to be the same.

Third, regardless of whether it is long-term, short-term or industry-adjusted, all CEO replacements generally had a positive impact on the post-merger performance. Downsizing had no significant impact on the post-merger performance, and the regression coefficient was very low. Lastly, all control variables, such as relatedness and whether the acquiring firms were in technology-intensive industries, were found to have no significant impact in all multiple regression analyzes.

Concerning moderation effects, the following observations were noted. First, moderation effects were observed only when the acquired firms' ROAs were not industry-adjusted. It is arguably because the acquired firms' post-merger performance generally does not surpass the industry average performance: it either converges with it or falls below it. In other words, any dramatic improvement in an acquired firm's performance derived from the acquisition synergy is quite unprecedented; in fact, in a majority of cases, such performance improvements remain only at the level of "normalizing" the firm.

Second, compared to downsizing, a CEO replacement was found to be a much more significant moderator variable. A CEO replacement was found to have a significant moderating effect on the relationship (1) between the debt-assets ratio and the acquired firm's short- and long-term ROA and (2) between the relative size and the acquired firm's long-term ROA. In the case of (1) where the regression coefficient is a positive value, this signifies that an acquiring firm with a high debt-assets ratio will view a $C E O$ replacement as a positive impact on the post-merger performance $(B=0.165$, 0.178). In the case of (2), the regression coefficient had a positive value and, thus, illustrates that, when the acquired firm's sales figures are relatively larger and exceed the figures for the acquiring firm, a CEO replacement has a positive impact on the post-merger performance. This was an unexpected result of this study, and since it has not been observed in other earlier papers, we recommend that a more detailed measurement tool be used to research this in the future. Although a CEO replacement has a significance level that is fairly low $(p<0.1)$, it has a relatively consistent moderating effect on the short-term post-merger performance, and as such, the results of our analysis support hypothesis 4 . 
Table 2. A correlation matrix.

\begin{tabular}{|c|c|c|c|c|c|c|c|c|c|c|c|c|}
\hline & Variable & 1 & 2 & 3 & 4 & 5 & 6 & 7 & 8 & 9 & 10 & 11 \\
\hline 1. & Short-term ROA & 1 & & & & & & & & & & \\
\hline 2. & Long-term ROA & $0.55^{* *}$ & 1 & & & & & & & & & \\
\hline 3. & Short-term industry-adjusted ROA & $0.98^{* *}$ & $0.53^{* *}$ & 1 & & & & & & & & \\
\hline 4. & Long-term industry-adjusted ROA & 0.13 & $0.72 * *$ & 0.17 & 1 & & & & & & & \\
\hline 5. & Cultural difference & -0.08 & $-0.24 *$ & -0.11 & -0.23 & 1 & & & & & & \\
\hline 6. & Debt-assets ratio & $0.24^{* *}$ & 0.15 & $0.26 * *$ & 0.08 & -0.16 & 1 & & & & & \\
\hline 7. & Relative size & -0.02 & 0.13 & -0.03 & -0.11 & -0.17 & -0.02 & 1 & & & & \\
\hline 8. & CEO replacement & $0.21 *$ & $0.38^{* *}$ & $0.20^{*}$ & $0.37^{* *}$ & -0.30 ** & 0.10 & -0.014 & 1 & & & \\
\hline 9. & Downsizing & 0.11 & 0.06 & 0.06 & 0.01 & -0.03 & -0.10 & -0.027 & 0.037 & 1 & & \\
\hline 10. & Relatedness & -0.08 & 0.02 & -0.08 & -0.15 & $-0.20 *$ & 0.03 & 0.16 & 0.013 & 0.081 & 1 & \\
\hline 11. & High technology & -0.01 & 0.01 & -0.01 & -0.10 & -0.04 & -0.21 * & 0.07 & -0.030 & 0.11 & 0.20 * & 1 \\
\hline
\end{tabular}

Table 3. A moderated multiple regression analysis: The acquired firms' short- and long-term ROA.

\begin{tabular}{|c|c|c|c|c|c|c|c|c|c|c|c|c|c|c|}
\hline \multirow{2}{*}{ Variable } & \multicolumn{7}{|c|}{ Short-Term ROA $(\mathrm{N}=113)$} & \multicolumn{7}{|c|}{ Long-Term ROA $(\mathrm{N}=70)$} \\
\hline & Model 1 & Model 2 & Model 3 & Model 4 & Model 5 & Model 6 & Model 7 & Model 1 & Model 2 & Model 3 & Model 4 & Model 5 & Model 6 & Model 7 \\
\hline Cultural difference & $\begin{array}{l}-0.015 \\
(0.100)\end{array}$ & $\begin{array}{c}0.110 \\
(0.140)\end{array}$ & $\begin{array}{l}-0.038 \\
(0.120)\end{array}$ & $\begin{array}{l}-0.010 \\
(0.099)\end{array}$ & $\begin{array}{l}-0.051 \\
(0.103)\end{array}$ & $\begin{array}{l}-0.017 \\
(0.100)\end{array}$ & $\begin{array}{l}-0.022 \\
(0.100)\end{array}$ & $\begin{array}{l}-0.080 \\
(0.133)\end{array}$ & $\begin{array}{l}-0.013 \\
(0.205)\end{array}$ & $\begin{array}{l}-0.051 \\
(0.152)\end{array}$ & $\begin{array}{l}-0.061 \\
(0.132)\end{array}$ & $\begin{array}{l}-0.087 \\
(0.135)\end{array}$ & $\begin{array}{l}-0.050 \\
(0.128)\end{array}$ & $\begin{array}{l}-0.081 \\
(0.135)\end{array}$ \\
\hline Debt-assets ratio & $\begin{array}{c}0.118^{* *} \\
(0.043)\end{array}$ & $\begin{array}{l}0.119^{* *} \\
(0.043)\end{array}$ & $\begin{array}{c}0.119^{* *} \\
(0.043)\end{array}$ & $\begin{array}{c}0.068 \\
(0.050)\end{array}$ & $\begin{array}{c}0.074 \\
(0.053)\end{array}$ & $\begin{array}{c}0.118^{* *} \\
(0.043)\end{array}$ & $\begin{array}{c}0.118^{* *} \\
(0.043)\end{array}$ & $\begin{array}{l}0.060 \\
(0.052)\end{array}$ & $\begin{array}{c}0.062 \\
(0.053)\end{array}$ & $\begin{array}{c}0.059 \\
(0.053)\end{array}$ & $\begin{array}{c}0.015 \\
(0.058)\end{array}$ & $\begin{array}{c}0.049 \\
(0.061)\end{array}$ & $\begin{array}{c}0.049 \\
(0.050)\end{array}$ & $\begin{array}{c}0.061 \\
(0.055)\end{array}$ \\
\hline Relative size & $\begin{array}{c}0.000 \\
(0.007)\end{array}$ & $\begin{array}{c}0.001 \\
(0.007)\end{array}$ & $\begin{array}{c}0.000 \\
(0.007)\end{array}$ & $\begin{array}{c}0.000 \\
(0.007)\end{array}$ & $\begin{array}{c}0.000 \\
(0.007)\end{array}$ & $\begin{array}{l}-0.002 \\
(0.009)\end{array}$ & $\begin{array}{l}-0.015 \\
(0.018)\end{array}$ & $\begin{array}{c}0.068 \\
(0.060)\end{array}$ & $\begin{array}{c}0.071 \\
(0.061)\end{array}$ & $\begin{array}{c}0.066 \\
(0.061)\end{array}$ & $\begin{array}{c}0.067 \\
(0.059)\end{array}$ & $\begin{array}{c}0.069 \\
(0.061)\end{array}$ & $\begin{array}{l}-0.016 \\
(0.067)\end{array}$ & $\begin{array}{c}0.053 \\
(0.256)\end{array}$ \\
\hline CEO replacement & $\begin{array}{l}0.166+ \\
(0.095)\end{array}$ & $\begin{array}{l}0.266^{*} \\
(0.123)\end{array}$ & $\begin{array}{l}0.168+ \\
(0.095)\end{array}$ & $\begin{array}{l}-0.046 \\
(0.148)\end{array}$ & $\begin{array}{l}0.168+ \\
(0.094)\end{array}$ & $\begin{array}{l}0.157 \\
(0.098)\end{array}$ & $\begin{array}{c}0.155 \\
(0.095)\end{array}$ & $\begin{array}{c}0.369^{* *} \\
(0.124)\end{array}$ & $\begin{array}{l}0.425^{*} \\
(0.180)\end{array}$ & $\begin{array}{c}0.364 \\
(0.126)\end{array}$ & $\begin{array}{c}0.124 \\
(0.191)\end{array}$ & $\begin{array}{l}0.373^{* *} \\
(0.126)\end{array}$ & $\begin{array}{l}0.235^{\dagger} \\
(0.131)\end{array}$ & $\begin{array}{c}0.369^{* *} \\
(0.126)\end{array}$ \\
\hline Downsizing & $\begin{array}{c}0.008 \\
(0.006)\end{array}$ & $\begin{array}{c}0.008 \\
(0.006)\end{array}$ & $\begin{array}{c}0.008 \\
(0.006)\end{array}$ & $\begin{array}{c}0.010 \\
(0.006)\end{array}$ & $\begin{array}{l}-0.027 \\
(0.026)\end{array}$ & $\begin{array}{c}0.008 \\
(0.006)\end{array}$ & $\begin{array}{c}0.008 \\
(0.006)\end{array}$ & $\begin{array}{c}0.003 \\
(0.007)\end{array}$ & $\begin{array}{c}0.003 \\
(0.007)\end{array}$ & $\begin{array}{c}0.003 \\
(0.007)\end{array}$ & $\begin{array}{c}0.004 \\
(0.006)\end{array}$ & $\begin{array}{l}-0.008 \\
(0.031)\end{array}$ & $\begin{array}{c}0.004 \\
(0.006)\end{array}$ & $\begin{array}{c}0.003 \\
(0.007)\end{array}$ \\
\hline
\end{tabular}


Table 3. Cont.

\begin{tabular}{|c|c|c|c|c|c|c|c|c|c|c|c|c|c|c|}
\hline \multirow{2}{*}{ Variable } & \multicolumn{7}{|c|}{ Short-Term ROA $(\mathrm{N}=113)$} & \multicolumn{7}{|c|}{ Long-Term ROA $(\mathrm{N}=70)$} \\
\hline & Model 1 & Model 2 & Model 3 & Model 4 & Model 5 & Model 6 & Model 7 & Model 1 & Model 2 & Model 3 & Model 4 & Model 5 & Model 6 & Model 7 \\
\hline Relatedness & $\begin{array}{l}-0.109 \\
(0.091)\end{array}$ & $\begin{array}{l}-0.115 \\
(0.090)\end{array}$ & $\begin{array}{l}-0.112 \\
(0.091)\end{array}$ & $\begin{array}{l}-0.108 \\
(0.089)\end{array}$ & $\begin{array}{l}-0.124 \\
(0.091)\end{array}$ & $\begin{array}{l}-0.112 \\
(0.091)\end{array}$ & $\begin{array}{l}-0.111 \\
(0.091)\end{array}$ & $\begin{array}{l}-0.066 \\
(0.126)\end{array}$ & $\begin{array}{l}-0.065 \\
(0.127)\end{array}$ & $\begin{array}{l}-0.059 \\
(0.128)\end{array}$ & $\begin{array}{l}-0.065 \\
(0.124)\end{array}$ & $\begin{array}{l}-0.072 \\
(0.128)\end{array}$ & $\begin{array}{l}-0.044 \\
(0.121)\end{array}$ & $\begin{array}{l}-0.066 \\
(0.127)\end{array}$ \\
\hline High-technology & $\begin{array}{c}0.075 \\
(0.093)\end{array}$ & $\begin{array}{c}0.071 \\
(0.093)\end{array}$ & $\begin{array}{l}0.078 \\
(0.094)\end{array}$ & $\begin{array}{c}0.090 \\
(0.092)\end{array}$ & $\begin{array}{l}0.094 \\
(0.094)\end{array}$ & $\begin{array}{c}0.078 \\
(0.094)\end{array}$ & $\begin{array}{c}0.084 \\
(0.094)\end{array}$ & $\begin{array}{c}0.084 \\
(0.139)\end{array}$ & $\begin{array}{c}0.083 \\
(0.140)\end{array}$ & $\begin{array}{c}0.078 \\
(0.141)\end{array}$ & $\begin{array}{c}0.135 \\
(0.140)\end{array}$ & $\begin{array}{l}0.096 \\
(0.143)\end{array}$ & $\begin{array}{c}0.034 \\
(0.134)\end{array}$ & $\begin{array}{c}0.085 \\
(0.140)\end{array}$ \\
\hline $\begin{array}{l}\text { Cultural difference } \\
* \text { CEO replacement }\end{array}$ & & $\begin{array}{l}-0.241 \\
(0.190)\end{array}$ & & & & & & & $\begin{array}{l}-0.106 \\
(0.246)\end{array}$ & & & & & \\
\hline $\begin{array}{l}\text { Cultural difference } \\
{ }^{*} \text { Downsizing }\end{array}$ & & & $\begin{array}{c}0.013 \\
(0.037)\end{array}$ & & & & & & & $\begin{array}{l}-0.061 \\
(0.041)\end{array}$ & & & & \\
\hline $\begin{array}{l}\text { Debt-assets ratio } \\
\text { * CEO replacement }\end{array}$ & & & & $\begin{array}{l}0.165+ \\
(0.089) \\
\end{array}$ & & & & & & & $\begin{array}{l}0.178+ \\
(0.107) \\
\end{array}$ & & & \\
\hline $\begin{array}{c}\text { Debt-assets ratio } \\
{ }^{*} \text { Downsizing }\end{array}$ & & & & & $\begin{array}{l}0.074 \\
(0.053)\end{array}$ & & & & & & & $\begin{array}{c}0.022 \\
(0.063)\end{array}$ & & \\
\hline $\begin{array}{l}\text { Relative size } \\
* \text { CEO Exchange }\end{array}$ & & & & & & $\begin{array}{c}0.005 \\
(0.014)\end{array}$ & & & & & & & $\begin{array}{l}0.303 * \\
(0.120)\end{array}$ & \\
\hline $\begin{array}{l}\text { Relative size } \\
{ }^{*} \text { Downsizing }\end{array}$ & & & & & & & $\begin{array}{c}0.011 \\
(0.012)\end{array}$ & & & & & & & $\begin{array}{c}0.012 \\
(0.209)\end{array}$ \\
\hline $\mathbf{R} 2$ & 0.125 & 0.139 & 0.126 & 0.153 & 0.142 & 0.127 & 0.132 & 0.199 & 0.201 & 0.201 & 0.234 & 0.201 & 0.274 & 0.199 \\
\hline F & & 1.607 & 0.128 & $3.442+$ & 1.981 & 0.156 & 0.823 & & 0.187 & 0.164 & $2.788+$ & 0.127 & $6.331^{*}$ & 0.003 \\
\hline
\end{tabular}


Table 4. A moderated multiple regression analysis: The acquired firms' short- and long-term industry-adjusted ROA.

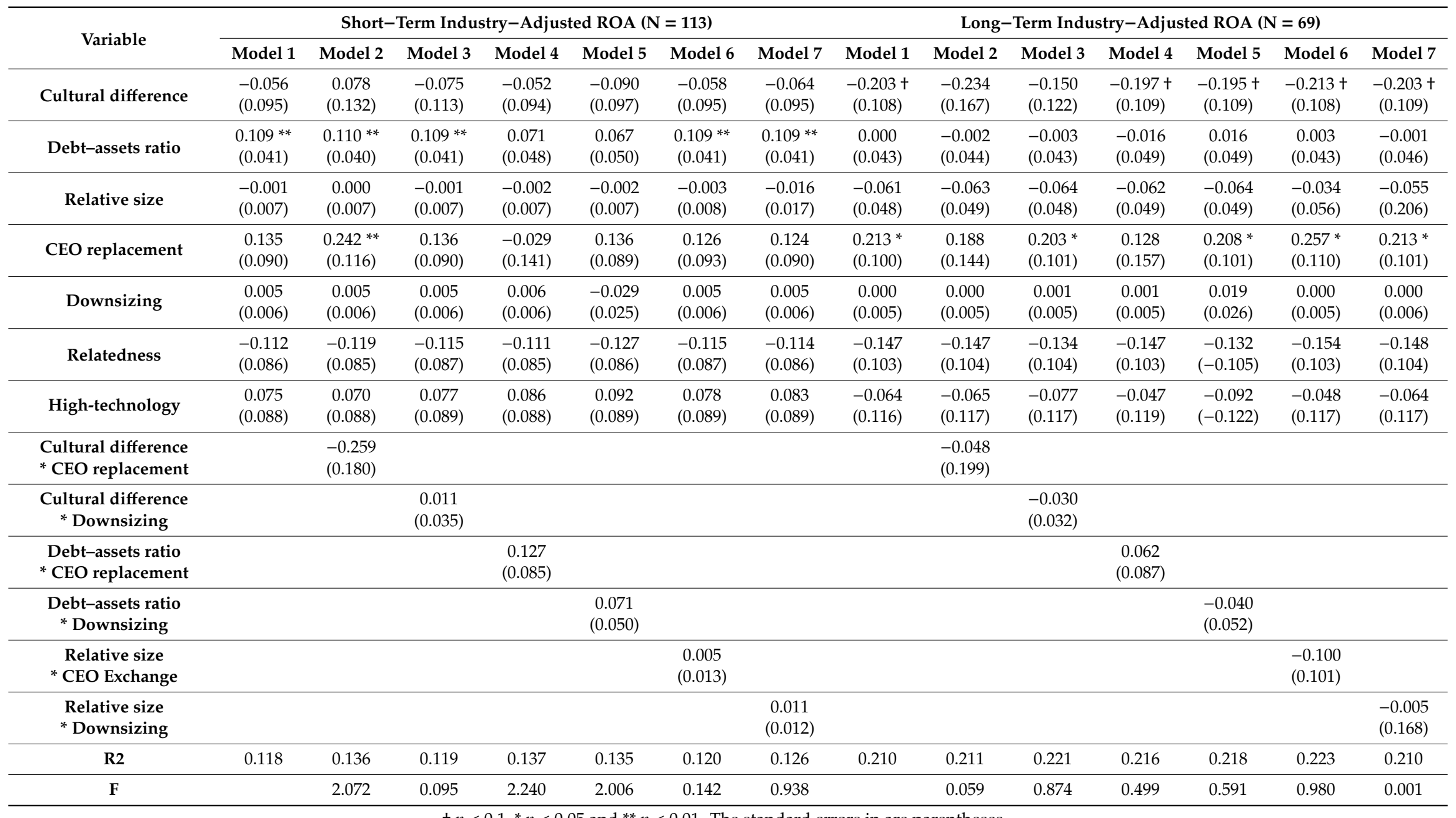


In sum, regarding the hypotheses derived from the essentialist concept of culture (hypothesis 1 and 3), the empirical results of this study partially support hypothesis 1 but dismiss hypothesis 3 . For the remaining two hypotheses derived from the social constructivist concept of culture (hypothesis 2 and 4), the results of our study support both hypotheses. In both situations of DMAs and CMAs, the variable of debt-assets ratio has appeared to be the most effective explanation regarding the short-term post-merger performance. Moreover, this variable is found to have a statistically significant moderating effect on the level of integration.

\section{Discussion}

The key contribution of this study is the empirical testing of the two ontologically as well as epistemologically different concepts of culture, namely the essentialist and the social constructivist concepts of culture, using the official pre- and post-merger performance data. To our knowledge, this study is the first of its kind to directly compare the validity of the two concepts of culture in a quantitative manner.

Research on acquisitions has long suspected that CMAs generally face more severe culture clashes during the post-merger integration processes due to a double-layered acculturation and, thus, may perform less than DMAs. However, prior studies have largely showed mixed results, and thus, some M\&A researchers argued that national cultural differences in CMAs are not to be seen merely as a source of culture clashes but as a source of complementarity as well, which in turn may boost the post-merger performance. This study seeks to explain why prior studies have so far failed to identify the main effects of national cultural differences on post-merger performance and ended up having the two contradictory hypotheses by providing the alternative theoretical framework, namely the social constructivist concept of culture. Although the concept itself has been widely accepted as the received view in other domains of social science (e.g., social anthropology or pedagogy), it seems that management studies have long neglected its theoretical implications. Considering this, this study empirically examines which of the two concepts of culture has more explanatory power in explaining the consequences of M\&As by comparing the financial performances of CMAs and DMAs that took place in the South Korean M\&A market.

Quite unexpectedly, the most significant difference between CMAs and DMAs was not found in the post- but rather in the premerger performance. This study could not find any statistically significant difference between CMAs and DMAs in the post-merger performances but in the case of the premerger performance, it was significantly lower in DMAs than CMAs (Tables 5 and 6). These results explain why $\mathrm{H} 1$ is only partially supported. Since the difference between the pre- and post-merger performances was much larger in DMAs, they demonstrated significantly better performance improvements than CMAs. It supports H1. However, in absolute terms, both CMAs and DMAs end up showing similar post-merger performances, which rejects $\mathrm{H} 1$.

Table 5. A comparison of the post-merger performance of domestic mergers and acquisitions (DMAs) and cross-border mergers and acquisitions (CMAs): the acquired firms' return on assets (ROA).

\begin{tabular}{ccccc}
\hline \multirow{2}{*}{ Acquired Firms' ROA } & \multirow{2}{*}{ Mean and Standard Deviation } & \multicolumn{2}{c}{ Classification } & \multirow{2}{*}{$\mathbf{t}$} \\
\cline { 3 - 4 } & & DMA & CMA & \\
\hline \multirow{3}{*}{$\mathrm{t}-5$} & M & -0.0058 & 0.0063 & \\
& SD & 0.3152 & 0.1515 & -0.201 \\
& N & 59 & 31 & \\
\hline \multirow{2}{*}{$t-4$} & M & -0.0999 & 0.0110 & \\
& SD & 0.3438 & 0.1803 & $-1.754^{+}$ \\
& N & 64 & 34 & \\
\hline \multirow{2}{*}{$t-3$} & M & -0.1252 & 0.0113 & \\
& SD & 0.6177 & 0.1809 & -1.311 \\
& N & 70 & 37 & \\
\hline
\end{tabular}


Table 5. Cont

\begin{tabular}{|c|c|c|c|c|}
\hline \multirow{2}{*}{ Acquired Firms' ROA } & \multirow{2}{*}{ Mean and Standard Deviation } & \multicolumn{2}{|c|}{ Classification } & \multirow{2}{*}{$\mathbf{t}$} \\
\hline & & DMA & CMA & \\
\hline \multirow{3}{*}{$t-2$} & M & -0.1587 & 0.0090 & \multirow{3}{*}{-2.597 * } \\
\hline & SD & 0.5044 & 0.1636 & \\
\hline & $\mathrm{N}$ & 73 & 39 & \\
\hline \multirow{3}{*}{$\mathrm{t}-1$} & M & -0.3970 & -0.0180 & \multirow{3}{*}{-0.441} \\
\hline & SD & 0.3807 & 0.1488 & \\
\hline & $\mathrm{N}$ & 75 & 45 & \\
\hline \multirow{3}{*}{$\mathrm{t}+1$} & M & -0.0086 & 0.0013 & \multirow{3}{*}{-0.298} \\
\hline & SD & 0.2214 & 0.1274 & \\
\hline & $\mathrm{N}$ & 76 & 56 & \\
\hline \multirow{3}{*}{$t+2$} & M & -0.0985 & -0.0289 & \multirow{3}{*}{-0.879} \\
\hline & SD & 0.6061 & 0.2449 & \\
\hline & $\mathrm{N}$ & 77 & 67 & \\
\hline \multirow{3}{*}{$t+3$} & M & -0.0554 & -0.0802 & \multirow{3}{*}{0.377} \\
\hline & SD & 0.2497 & 0.4380 & \\
\hline & $\mathrm{N}$ & 58 & 63 & \\
\hline \multirow{3}{*}{$t+4$} & M & -0.0416 & 0.0075 & \multirow{3}{*}{-0.678} \\
\hline & SD & 0.4167 & 0.2966 & \\
\hline & $\mathrm{N}$ & 41 & 56 & \\
\hline \multirow{3}{*}{$t+5$} & M & 0.0121 & -0.0040 & \multirow{3}{*}{0.394} \\
\hline & SD & 0.2162 & 0.1518 & \\
\hline & $\mathrm{N}$ & 32 & 49 & \\
\hline
\end{tabular}

Table 6. A comparison of the post-merger performance of DMAs and CMAs: the acquired firms' industry-adjusted ROA.

\begin{tabular}{|c|c|c|c|c|}
\hline \multirow{2}{*}{$\begin{array}{c}\text { Acquired Firms' } \\
\text { Industry-Adjusted ROA }\end{array}$} & \multirow{2}{*}{ Mean and Standard Deviation } & \multicolumn{2}{|c|}{ Classification } & \multirow{2}{*}{$t$} \\
\hline & & DMA & CMA & \\
\hline \multirow{3}{*}{$t-5$} & M & -0.0112 & 0.0255 & \\
\hline & SD & 0.3279 & 0.2083 & -0.420 \\
\hline & $\mathrm{N}$ & 49 & 16 & \\
\hline \multirow{3}{*}{$t-4$} & M & -0.1206 & -0.0108 & \\
\hline & SD & 0.3643 & 0.1764 & -1.404 \\
\hline & $\mathrm{N}$ & 56 & 24 & \\
\hline \multirow{3}{*}{$t-3$} & M & -0.1361 & 0.0057 & \\
\hline & SD & 0.6554 & 0.1866 & -1.198 \\
\hline & $\mathrm{N}$ & 66 & 32 & \\
\hline \multirow{3}{*}{$t-2$} & M & -0.1607 & 0.0215 & \\
\hline & SD & 0.4524 & 0.1649 & $-3.080^{* *}$ \\
\hline & $\mathrm{N}$ & 73 & 39 & \\
\hline \multirow{3}{*}{$t-1$} & M & -0.0748 & -0.0336 & \\
\hline & SD & 0.3589 & 0.1569 & -0.864 \\
\hline & $\mathrm{N}$ & 75 & 45 & \\
\hline \multirow{3}{*}{$t+1$} & M & -0.0354 & -0.0310 & \\
\hline & SD & 0.2145 & 0.1280 & -0.137 \\
\hline & $\mathrm{N}$ & 76 & 56 & \\
\hline \multirow{3}{*}{$t+2$} & $\mathrm{M}$ & -0.1300 & -0.0561 & \\
\hline & SD & 0.6100 & 0.2468 & -0.927 \\
\hline & $\mathrm{N}$ & 77 & 67 & \\
\hline \multirow{3}{*}{$t+3$} & M & -0.0937 & -0.1220 & \\
\hline & SD & 0.2501 & 0.4415 & 0.427 \\
\hline & $\mathrm{N}$ & 58 & 62 & \\
\hline \multirow{3}{*}{$t+4$} & $\mathrm{M}$ & -0.0780 & -0.0310 & \\
\hline & SD & 0.4216 & 0.2959 & -0.641 \\
\hline & $\mathrm{N}$ & 41 & 55 & \\
\hline \multirow{3}{*}{$t+5$} & M & -0.0179 & -0.0408 & \\
\hline & SD & 0.2163 & 0.1474 & 0.568 \\
\hline & $\mathrm{N}$ & 32 & 49 & \\
\hline
\end{tabular}

${ }^{\dagger} p<0.1,{ }^{*} p<0.05$ and ${ }^{* *} p<0.01$. 
These empirical evidences suggest that national cultural differences may not be a critical issue as it is usually hypothesized at least in terms of financial performance. Perhaps, as the cultural diversity hypothesis suggests, national cultural differences are not to be seen merely as obstacles to be overcome but rather as valuable assets to be utilized, or more correctly, the existence of national cultural differences themselves does not guarantee at all whether culture clashes during a post-merger integration may occur or not. It suggests that management scholars seem to have, so far, overemphasized the negative view of national cultural differences [49,50].

This study also successfully showed that the single most important factors for the success of both CMAs and DMAs—at least in the Korean M\&A market-was a CEO replacement. Conducting the exact same statistical procedure with the CMA samples yielded the same result (although with a slightly less statistical significance). Also, the positive impact of a CEO replacement on the post-merger performance was more apparent when the acquired firms' debt-assets ratio was relatively high. While some researchers argued that the low level of integration (at least during the early stages of integration) was desirable in order to enhance the post-merger performance when cultural differences were evident, the results of the current study could not find any empirical support for their argument. In line with this and coupled with the evidence that CMAs and DMAs showed a similar post-merger performance in absolute terms, one can possibly argue that what matters most for an M\&A to be successful from a cultural perspective is not "objective" cultural differences but rather the intergroup status relations between the acquiring and acquired firms, as suggested by the social constructivist concept of culture. In other words, when the acquired employees subjectively perceive that they deserve to be acquired due to a poor performance prior to M\&As, they are likely to accept their "inferior" social status against the acquiring employees as well as a CEO replacement relatively easily regardless of whether the acquiring firms are foreign or domestic. It may, in turn, stimulate knowledge transfer between the acquiring and acquired firms and ultimately improve the post-merger performance [16].

The importance of intergroup status relations has been repeatedly stressed by a number of prior M\&A studies in the field of social psychology but most of them did not examined it from a "business" perspective using the post-merger performance as a dependent variable [37]. Also, although there are a growing number of management studies that have begun to stress the importance of status positions for M\&A success recently, most of them except a few are case studies and suffer from the issue of generalizability [51,52].

Based on the discussion so far, national cultural differences may not be simply seen as a given threat to gaining sustainable competitive advantages. It suggests that whether they are to be seen as an opportunity or a threat largely depends on the social context in which they unfold. In this vein, some M\&A researchers interestingly point out that although cultural differences are often regarded as the culprit behind a variety of organizational difficulties that may take place when two firms merge, it does so only when "things are not going well" [53]. In other words, cultural differences per se, although they do explain quite nicely ex post what kinds of organizational difficulties may occur and why, cannot be seen as a direct source of such organizational difficulties.

In order to achieve a long-term sustainable M\&A success, especially from a cultural perspective, managers in the acquired firms are, thus, strongly advised to pay close attention to the nature of the premerger social and economic conditions, not national cultural differences per se, and act accordingly (e.g., CEO replacement). There has been a series of cultural studies that have documented in detail what devastating effects national cultural differences may have in various forms of international business partnerships. However, in the context of CMAs, culture clashes appear to be not the result of cultural differences but rather the result of group conflicts arising from the course of the post-merger integration processes.

The empirical evidence of this study also offered several other interesting results. First, the variable that can be used to predict the acquired firm's post-merger performance is different depending on whether it is from the perspective of short-term or long-term. Among the variables used to measure the stability and legitimacy of intergroup status relations, the debt-assets ratio was found to have 
a positive effect on the acquired firm's short-term performance while the dichotomous variable of cultural difference yields a negative impact on the acquired firm's long-term performance. It is, thus, recommended that future studies examining the determinants of a post-merger performance may distinguish between short-term and long-term determinants.

Second, as already discussed, this study has found that more than any other variable, CEO replacement has consistently emerged as a variable that has had a positive impact on the post-merger performance. What is interesting here is that previous studies with non-Korean samples noted that the opposite was true [54]. It is difficult to determine whether such results only appear as a unique phenomenon in the Korean market due to its limited nature or whether such differences occur as a result of some problems in methodology.

Third, unlike foreign companies, Korean acquiring firms were found to be relatively bolder in selecting a firm for acquisition. Additionally, they were generally more inclined to replacing the CEO of the acquired firm. This conclusion will likely be a new area of research in the future.

\section{Conclusions}

The purpose of this study was to compare the post-merger performances of CMAs and DMAs in the context of the Korean M\&A market and to examine exactly under what circumstances national cultural differences are to have either a positive or a negative impact on a sustainable M\&A success. In sum, this study could not find any statistically significant performance differences between CMAs and DMAs. However, the stability and legitimacy of intergroup status relations turned out to have a considerable impact on the post-merger performance of both.

Although this study does not look into post-merger integration per se, we believe the following implications can be safely drawn for M\&A practitioners based on the results of the study. Firstly, it is important to keep in mind that the acquired employees can interpret "objective" national cultural differences in completely different manners depending on how the social relations between the acquiring and acquired firms actually unfold [55]. One of the most striking examples can be found in the case study of Volvo Construction Equipment's (a subsidiary of the Volvo Group) acquisition of the Division of Construction Equipment in Samsung Heavy Industry, written by some of the authors prior to this study [52]. Throughout the post-merger integration process, the acquired firm pursued a series of organizational changes that clearly did not "fit" the Korean national culture at all, and thus, a strong employee resistance was seemingly inevitable. However, the acquired employees did not perceive the organizational changes in a uniform way (as the essentialist concept of culture predicts). Rather, they perceived them in significantly different ways depending on their personal experiences before and after the acquisition.

Secondly, following the first implication, it would be a good idea for acquiring managers to pay close attention to the development process of the acquired employees' post-merger identification. Do they successfully identify themselves as a legitimate member of an acquiring firm or do they hesitate to do so? If the latter is the case, then acquiring managers may fruitfully try to find out whether there is any "obstacle" hindering their favorable identification with an acquiring firm. In this regard, when the intergroup status relations between the acquiring and acquired firms are stable and legitimate, it may be desirable to aggressively pursue a high level of integration in order to maximize the synergetic effects (e.g., CEO exchange). Again, the case study described above can be a good example here. What was striking in this case study was that the acquired employees who showed the most positive attitude toward the acquiring firm and, thus, to a great extent identified themselves with it turned out to also have experienced the highest level of integration.

Based on the discussions so far, the next logical step for future research is to look closely into a variety of contingency variables (which can be cultural or noncultural) that seemingly moderate the effects of cultural differences on the post-merger performance as well as a variety of noneconomic integration outcomes, e.g., post-merger identification. In this sense, the authors strongly believe that a 
large number of variables can be studied in a meaningful way such as different types of integration approaches [56], specific managerial interventions [57], social controls [58], etc.

This research paper has several limitations. First, the limited sample size may make it difficult to give credence to the results of this study. However, the sample size can be significantly increased or decreased depending on the selection criteria. For the purposes of this study, we deliberately used strict criteria to limit our research to only "pure" M\&A cases of which the objective was to gain long-term sustainable competitive advantages. It inevitably resulted in a smaller sample size. Second, there may be some limitations regarding the validity of the measurement tools utilized. Rather than conducting surveys or in-depth interviews, this paper relied entirely upon secondary data sources when measuring variables. As a result, there are many varying degrees of ambiguity in interpreting the results of the research. Third, some of the important M\&A-specific variables were not included in this study, such as previous M\&A experience, knowledge transfer between firms and employee resistance. Indeed, this study could have been more interesting if more "in-depth" organization-level data had been collected using a survey method.

All of these were anticipated due to the limitations associated with collecting data using the financial statements of acquired firms. The significance of this paper, we believe, lies in that the cultural aspects of M\&A were addressed from the perspective of the social constructivist concept of culture which, to date, has been largely neglected in extant literature and its validity is empirically demonstrated based on a more "objective" measurement. It is recommended that future studies find ways to create a more accurate measurement tool.

Author Contributions: S.-J.L. organized the model, collected data and finalized the paper. S.K. analyzed the data and prepared the draft. J.K. developed the theory, interpreted the results and revised the paper.

Funding: This work was supported by the Hankuk University of Foreign Studies Research Fund of 2019.

Acknowledgments: The authors would like to thank the anonymous reviewers for their helpful and constructive comments that greatly contributed to improving the final version of the paper.

Conflicts of Interest: The authors declare no conflict of interest.

\section{References}

1. Morck, R.; Schleifer, A.; Vishny, R.W. Do Managerial Objectives Drive Bad Acquisitions? J. Financ. 1990, 45, 31-48. [CrossRef]

2. Pablo, A.L. Determinants of Acquisition Integration Level: A Decision-Making Perspective. Acad. Manag. J. 1994, 37, 803-836.

3. Zollo, M.; Singh, H. Deliberate Learning in Corporate Acquisitions: Post-merger Strategies and Integration Capability in US Bank Mergers. Strateg. Manag. J. 2004, 25, 1233-1256. [CrossRef]

4. Olie, R. Culture and Integration Problems in International Mergers and Acquisitions. Eur. Manag. J. 1990, 8, 206-215. [CrossRef]

5. Hofstede, G.; Hofstede, G.J.; Minkov, M. Cultures and Organizations: Software of the Mind, 3rd ed.; McGraw Hill Professional: New York, NY, USA, 2010.

6. Björkman, I.; Stahl, G.K.; Vaara, E. Cultural Differences and Capability Transfer in Cross-Border Acquisitions: The Mediating Roles of Capability Complementarity, Absorptive Capacity, and Social Integration. J. Int. Bus. Stud. 2007, 38, 658-672. [CrossRef]

7. Morosini, P.; Shane, S.; Singh, H. National Cultural Distance and Cross-Border Acquisition Performance. J. Int. Bus. Stud. 1998, 29, 137-158. [CrossRef]

8. Datta, D.K.; Puia, G. Cross-Border Acquisitions: An Examination of the Influence of Relatedness and Cultural Fit on Shareholder Value Creation in U.S. Acquiring Firms. Manag. Int. Rev. 1995, 35, 337-359.

9. Dewenter, K.L. Does the Market React Differently to Domestic and Foreign Takeover Announcement: Evidence from the U.S. Chemical and Retail Industries. J. Financ. Econ. 1995, 37, 421-441. [CrossRef]

10. Larsson, R.; Finkelstein, S. Integrating Strategic, Organizational, and Human Resource Perspectives on Mergers and Acquisitions: A Case Survey of Synergy Realization. Organ. Sci. 1999, 10, 1-27. [CrossRef] 
11. Xie, E.; Reddy, K.S.; Liang, J. Country-Specific Determinants of Cross-Norder Mergers and Acquisitions: A Comprehensive Review and Future Research Directions. J. World. Bus. 2017, 52, 127-183. [CrossRef]

12. Hastrup, K. A Passage to Anthropology: Between Experience and Theory; Routledge: London, UK, 1995.

13. Schein, E.H. Culture: The Missing Concept in Organization Studies. Adm. Sci. Quart. 1996, 41, $229-240$. [CrossRef]

14. Nahavandi, A.; Malekzadeh, A.R. Acculturation in Merger and Acquisitions. Acad. Manag. Rev. 1988, 13, 79-90. [CrossRef]

15. Laurent, A. The Cultural Diversity of Western Conceptions of Management. Int. Stud. Manag. Organ. 1983, 13, 75-96. [CrossRef]

16. Ahammad, N.F.; Tarba, S.Y.; Liu, Y.; Glaister, K.W. Knowledge Transfer and Cross-Border Acquisition Performance: The Imact of Cultural Distance and Employee Retention. Int. Bus. Rev. 2016, 25, 66-75. [CrossRef]

17. Rottig, D.; Reus, T.H.; Tarba, S.Y. The Impact of Culture on Mergers and Acquisitions: A Third of a Century Research. In Advances in Mergers \& Acquisitions; Cooper, C.L., Finkelstein, S., Eds.; Emerald Publishing: Bingley, UK, 2013; Volume 12, pp. 135-172. ISBN 978-1-78190-836-5.

18. Boateng, A.; Du, M.; Bi, X.; Lodorfos, G. Cultural Distance and Value Creation of Cross-Border M\&A: The Moderating Role of Acquirer Characteristics. Int. Rev. Financ. Anal. 2018. [CrossRef]

19. Vasilaki, A. Culture Distance and Cross-Border Acquisition Performance: The Moderating Effect of Transformational Leadership. Eur. J. Int. Manag. 2012, 5, 394-412. [CrossRef]

20. Ahern, R.A.; Daminelli, D.; Fracassi, C. Lost in Translation? The Effect of Cultural Values on Mergers Around the World. J. Financ. Econ. 2015, 117, 165-189. [CrossRef]

21. Chakrabarti, R.; Gupta-Mukherjee, S.; Jayaraman, N. Mars-Venus Marriage: Culture and Cross-Border M\&A. J. Int. Bus. Stud. 2009, 40, 216-236.

22. Huang, Z.; Zhu, H.; Brass, D.J. Cross-Border Acquisitions and the Asymmetric Effect of Power Distance Value Difference on Long-Term Post-Acquisition Performance. Strateg. Manag. J. 2016, 38, 972-991. [CrossRef]

23. Reus, T.H.; Lamont, B.T. The Double-Edged Sword of Cultural Distance in International Acquisitions. J. Int. Bus. Stud. 2009, 40, 1298-1316. [CrossRef]

24. Slangen, A.H.L. National Cultural Distance and Initial Foreign Acquisition Performance: The Moderating Effect of Integration. J. World Bus. 2006, 41, 161-170. [CrossRef]

25. Kleppestø, S. Kultur Och Identitiet vid Företagsuppköp och Fusioner; Nerenius och Santerus: Stockholm, Sweden, 1993.

26. Delanty, G. The Cultural Foundations of a Republican Polity: Culture as Communication. Republic 2003, 3, $27-39$.

27. Gertsen, M.C.; Søderberg, A.M.; Torp, J.E. Different Approaches to the Understanding of Culture in Mergers and Acquisitions. In Cultural Dimensions of International Mergers and Acquisitions; Gersten, M.C., Søderberg, A.M., Torp, J.E., Eds.; de Gruyter: Berlin, Germany, 1998; pp. 17-38.

28. White, D.G. Rethinking Culture: Embodied Cognition and the Origin of Culture in Organizations; Routledge: New York, NY, USA, 2017.

29. Meyerson, D.; Martin, J. Cultural Change: An Integration of Three Different Views. J. Manag. Stud. 2007, 24, 623-647. [CrossRef]

30. Risberg, A. Ambiguity and Communication in Cross-Cultural Acquisitions: Towards a Conceptual Framework. Leadersh. Org. Dev. J. 1997, 18, 257-266. [CrossRef]

31. Kleppestø, S. The Construction of Social Identities in Mergers and Acquisitions. In Mergers and Acquisitions: Managing Culture and Human Resources; Stahl, G.K., Mendenhall, M., Eds.; Standford Business Press: Standford, CA, USA, 2005; pp. 130-151.

32. Kleppestø, S. A Quest for Social Identity: The Pragmatics of Communication in Mergers and Acquisitions. In Cultural Dimensions of International Mergers and Acquisitions; Gersten, M.C., Søderberg, A.M., Torp, J.E., Eds.; de Gruyter: Berlin, Germany, 1998; pp. 147-165.

33. Gertsen, M.C.; Søderberg, A.M. Foreign Acquisitions in Denmark: Cultural and Communicative Dimension. In Cultural Dimensions of International Mergers and Acquisitions; Gersten, M.C., Søderberg, A.M., Torp, J.E., Eds.; de Gruyter: Berlin, Germany, 1998; pp. 167-196.

34. Blake, R.R.; Mouton, J.S. How to Achieve Integration on the Human Side of Merger. Organ. Dyn. 1985, 13, 41-56. [CrossRef]

35. Buono, A.F.; Bowditch, J.L. The Human Side of Mergers and Acquisitions; Jossey-Bass Publishers: San Francisco, CA, USA, 1989. 
36. Haunschild, P.R.; Moreland, R.L.; Murrell, A.J. Sources of Resistance to Mergers between Groups. J. Appl. Soc. Psychol. 1994, 24, 1150-1178. [CrossRef]

37. Lipponen, J.; Wisse, B.; Jetten, J. The Different Paths to Post-Merger Identification for Employees from High and Low Status Pre-Merger Organizations. J. Organ. Behav. 2017, 38, 692-711. [CrossRef]

38. Bauer, F.; Matzler, K. Antecedents of M\&A Success: The Role of Strategic Complementarity, Cultural Fit, and Degree and Speed of Integration. Strateg. Manag. J. 2014, 35, 269-291.

39. Datta, D.K.; Grant, J.H. Relationship between Type of Acquisition, the Autonomy Given to the Acquired Firm, and Acquisition Success: An Empirical Analysis. J. Manag. 1990, 16, 29-44. [CrossRef]

40. Bauer, F.; Matzler, K.; Wolf, S. M\&A and Innovation: The Role of Integration and Cultural Differences: A Central European Targets Perspective. Int. Bus. Rev. 2016, 25, 76-86.

41. Rousseau, D.M. Invited Essay: Why Workers Still Identify with Organizations. J. Organ. Behav. 1998, 19, $217-233$. [CrossRef]

42. Bartels, J.; Douwes, R.; de Jong, M.; Pruyn, A. Organizational Identification during a Merger: Determinants of Employees' Expected Identification with the New Organization. Brit. J. Manag. 2006, 17, 49-67. [CrossRef]

43. van Knippenberg, D.; van Knippenberg, B.; Monden, L.; de Lima, F. Organizational Identification After a Merger: A Social Identity Perspective. Br. J. Soc. Psychol. 2002, 41, 233-252. [CrossRef] [PubMed]

44. Hogg, M.A.; Terry, D.J. Social Identity and Self-Categorization Processes in Organizational Contexts. Acad. Manag. Rev. 2000, 25, 121-140. [CrossRef]

45. Lutbakin, M.; Calori, R.; Very, P.; Veiga, J.F. Managing Mergers Across Borders: A Two-Nation Exploration of a Nationally Bound Administrative Heritage. Organ. Sci. 1998, 9, 670-684.

46. Chatterjee, S.; Lubatkin, M.H.; Schweiger, D.M.; Weber, Y. Cultural Differences and Shareholder Value in Related Mergers: Linking Equity and Human Capital. Strateg. Manag. J. 1992, 13, 319-334. [CrossRef]

47. Homburg, C.; Bucerius, M. Is Speed of Integration Really a Success Factor of Mergers and Acquisitions? An Analysis of the Role of Internal and External Relatedness. Strateg. Manag. J. 2006, 27, 347-367. [CrossRef]

48. Meglio, O.; Risberg, A. The (Mis)measurement of M\&A Performance-A Systematic Narrative Literature Review. Scand. J. Manag. 2011, 27, 418-433.

49. Stahl, G.; Tung, R.L.; Kostova, T.; Zellmer-Bruhn, M. Widening the Lens: Rethinking Distance, Diversity, and Foreignness in International Business Research Through Positive Organizational Scholarship. J. Int. Bus. Stud. 2016, 47, 621-630. [CrossRef]

50. Stahl, G.; Tung, R.L. Towards a More Balanced Treatment of Culture in International Business Studies: The Need for Positive Cross-Cultural Scholarship. J. Int. Bus. Stud. 2015, 46, 391-411. [CrossRef]

51. Yildiz, E.H. Not All Differences are the Same: Dual Role of Status and Cultural Distance in Sociocultural Integration in Cross-Border M\&As. J. Int. Manag. 2014, 20, 25-37.

52. Lee, S.-J.; Kim, J.; Park, B.I. Culture Clashes in Cross-Border Mergers and Acquisitions: A Case Study of Sweden's Volvo and South Korea's Samsung. Int. Bus. Rev. 2015, 24, 580-593. [CrossRef]

53. Kanter, R.M.; Corn, R.I. Do Cultural Differences Make a Business Difference? Contextual Factors Affecting Cross-Cultural Relationship Success. J. Manag. Dev. 1994, 13, 5-23. [CrossRef]

54. Cannella, A.A.; Hambrick, D.C. Effects of Executive Departures on the Performance of Acquired Firms. Strateg. Manag. J. 1993, 14, 137-152. [CrossRef]

55. Maeks, M.L.; Mirvis, P.H. A Framework for the Human Resources Role in Managing Culture in Mergers and Acquisitions. Hum. Resour. Manag. 2011, 50, 859-877.

56. Rodríguez-Sánchez, J.-L.; Ortiz-de-Urbina-Criado, M.; Mora-Valentín, E.-M. Human Resource Management and Mergers and Acquisitions: Perspectives and Challenges. In Advances in Business and Management; Nelson, W.D., Ed.; Nova Science Publisher: New York, NY, USA, 2015; Volume 7, pp. 67-87.

57. Steigenberger, N. The Challenge of Integration: A Review of the M\&A Integration Literature. Int. J. Manag. Rev. 2016, 19, 408-431.

58. Rich, D.; Bruce, L.T.; Reginald, H.J. Managerial Control in Mergers of Equals: The Role of Political Skill. J. Manag. Issues 2016, 28, 50-66.

(C) 2019 by the authors. Licensee MDPI, Basel, Switzerland. This article is an open access article distributed under the terms and conditions of the Creative Commons Attribution (CC BY) license (http://creativecommons.org/licenses/by/4.0/). 